\title{
Production of biodiesel from vegetable oils
}

\author{
Por José María Cerveró, José Coca and Susana Luque*
}

\author{
Department of Chemical and Environmental Engineering, \\ University of Oviedo, \\ C/. Julián Clavería, 8, 33071 Oviedo \\ Corresponding author: sluque@uniovi.es
}

\section{RESUMEN}

\section{Producción de biodiésel a partir de aceites vegetales}

El biodiésel se produce mediante la transesterificación de triglicéridos, presentes en grasas animales o aceites vegetales, en un proceso en el que un alcohol de bajo peso molecular desplaza a la glicerina. La mezcla de esteres así resultante posee unas propiedades físico-químicas similares a las del diésel procedente de petróleo. En este artículo se revisan las vías de síntesis de biodiésel mediante la transesterificación catalítica de aceites vegetales. Aunque actualmente a escala industrial solo se producen ésteres metílicos, también se ha considerado el uso de etanol, ya que éste se obtiene también de fuentes renovables, generando así un combustible más limpio y biocompatible.

PALABRAS-CLAVE: Biodiésel - Ésteres de ácidos grasos - Transesterificación - Triglicéridos.

\section{SUMMARY}

\section{Production of biodiesel from vegetable oils}

Biodiesel is produced by transesterification of triglycerides present in animal fat or vegetable oils, by displacing glycerine with a low molar mass alcohol. This resulting ester mixture has physico-chemical properties similar to those of petroleum diesel.

This paper reviews the synthetic paths that lead to biodiesel by means of the catalytic transesterification of vegetable oils. Although methyl esters are at present the only ones produced at industrial scale, the use of ethanol, which can also be obtained from renewable resources, has been considered, since it would generate a cleaner and more biocompatible fuel.

KEY-WORDS: Biodiesel - Fatty Acid Esters Transesterification - Triglycerides.

\section{INTRODUCTION}

The energy crisis of 1973 and the unstable situation in the Middle East have led to a number of approaches to reduce dependence on fossil fuels. This has resulted in environmentally friendlier alternatives which allow obtaining energy from non- conventional and renewable energy sources (i.e., biomass) with a similar efficiency output.

With respect to other renewable energy sources (hydraulic, eolic, wave energy, etc.), biomass has the advantage that its chemical structure can be chemically modified, yielding a product which is structurally-similar to petroleum. Therefore, fuels derived from renewable biomass can be used in today's diesel engines, replacing petroleum-derived fuels for transportation purposes.

Fuels derived from biomass have several advantages (Sarbolouki and Moacanin, 1980):

- No sulphur emissions are produced during theirs combustion because biomass lacks sulphur compounds in its composition.

- No particulate matter or PAH's (polycyclic aromatic hydrocarbons) are produced during their combustion.

- Biomass-derived $\mathrm{CO}_{2}$ in fuel emissions is recycled in the feedstock production.

Fuels currently produced from biomass are ethanol and biodiesel. Ethanol is obtained from the fermentation of sugars, present in the vegetable structure, while biodiesel is produced by catalytic transesterification of vegetable oils with short or middle size-chain alcohols (Wright, 1988; McCoy, 1998). Biodiesel shows the greatest energy potential and will be the main topic in this work.

The direct use of vegetable oils as fuels has not been satisfactory in diesel engines, because of their high viscosity, low volatility, polyunsaturated compound content, high content of free fatty acids, resins and rubber (formed by oxidation or spontaneous polymerization), and cinder deposits.

Efforts have been made in the chemical modification of vegetable oils to obtain fuels suitable for combustion engines, in particular the synthesis of fatty acid esters, yielding the so-called biodiesel.

Today, biodiesel is produced by transesterification of fatty acids in vegetable oils, using an alkaline catalyst (sodium or potassium hydroxide at $80^{\circ} \mathrm{C}$ ), a reaction that proceeds with a 
very high yield. However, the process requires a complex downstream by-product separation and some wastewater problems may arise. The glycerol generated as a by-product is accompanied by the alkali employed as a catalyst, and has to be treated either as a waste stream or purified for further applications. Moreover, free fatty acids and water present in the vegetable oil form the corresponding salts and are extracted with the wash water along with small amounts of glycerol, methanol and catalyst. The alkaline water stream waste requires appropriate treatment. A simple life-cycle analysis shows that the conversion of vegetable oils to biodiesel requires a substantial amount of energy, because of the high temperature at which the reaction is carried out (Van Gerpen, 2006).

An alternative path for the production of biodiesel involves the use of enzymes as catalysts. The enzymatic catalyzed reaction generates fewer waste streams, and enzymes can convert both triglycerides and free fatty acids into biodiesel, resulting in an efficient process, under mild reaction conditions. Phase stability leads to a product with few impurities, and the aqueous phase which contains the catalyst is very stable. Furthermore, the reaction does not require solvents, and hence there is no need for a special treatment to recover the solvent for reuse. The enzymatic catalyzed process requires less energy but it has some drawbacks, such as the high cost of enzymes and the need for a careful control of reaction parameters (Ma and Hanna, 1999; Fukuda et al., 2001, Aracil et al., 2006).

\section{PHYSICOCHEMICAL PROPERTIES OF BIODIESEL}

Biodiesel is a liquid fuel produced from a variety of natural oils, such as vegetables oils, animal fats, or even waste cooking oils. It contains monoalkylic esters with hydrocarbon chains in the range of 14 22 carbon atoms, capable of combusting properly in conventional diesel engines (Vicente Crespo et al, 2001).

Although most commonly used oils are soybean, rapeseed, and palm or sunflower, biodiesel can be produced from more than 300 vegetable species, depending on their availability in the biodiesel production area. The use of waste cooking oils has the advantage that they are recycled, avoiding a significant environmental problem.

Depending on the feedstock, biodiesel has different names:

- RME: Rapeseed methyl ester

- SME: Soybean/sunflower methyl ester

- PME: Palm Methyl Ester

- FAME: Fatty Acid Methyl Ester, generally referred to another vegetable or waste cooking oils

Vegetable oils and animal fats are extracted and pressed to obtain the crude oil, which contains free fatty acids, phospholipids, sterols, water, strong odor compounds and impurities. Even refined oils always contain a small amount of free fatty acids and water. This fact has a strong effect on the transesterification reaction when inorganic catalysts are employed.

Vegetable oils have a wide variety of fatty acid composition, depending on their source. Among the fatty acids, oleic acid is particularly stable to thermal oxidation, because it only contains one double bond in its molecular structure. Although most sunflower oils have about $20 \%$ of oleic acid, hybrid varieties may reach an $80 \%$ content. So this oil has been of special interest for the synthesis of esters used as biofuels and lubricants (Mittelbach, 1990; Dossat et al., 1999; Dossat et al., 2002).

Biodiesel typically contains up to fourteen different types of FAMEs. Their relative amounts greatly influence the properties of the resulting biodiesel. For example, a high content of saturated fatty acids in the raw feedstock (i.e. myristic, palmitic, stearic acids) rises turbidity and the cetane number, decreases $\mathrm{NO}_{x}$ emissions, and shows better stability. Furthermore, a high ratio of polyunsaturated fatty acids (i.e. linoleic or linolenic acids) has the opposite effect (Ma and Hanna, 1999).

Oleic and linoleic acids are the main fatty acids in sunflower oil, both with a 19-carbon atom chain, oleic acid with one double bond and linoleic acid with two. Typically linoleic acid is about $80 \%$ of the free fatty acid content, though some varieties have around $70 \%$ of oleic acid.

Biodiesel can be obtained by transesterification of fatty acids, either with methanol or ethanol. Ethanol, being even more expensive than methanol, can be obtained from renewable resources, and the resulting biodiesel is a fully renewable fuel.

The synthetic path for ethylic esters of fatty acids is very similar to the one for methyl esters. Glycerol removal is, in principle, easier to carry out, but vigorous stirring is needed. Ethanol purity is essential, with respect to its water content, since water occurrence in the reaction medium decreases selectivity (Peterson, 1996). Potassium hydroxide is the most suitable catalyst in this process (Shaw et al., 1991).

\section{COMPARISON OF BIODIESEL AND PETROLEUM DIESEL}

As shown in Table 1, biodiesel and petroleum diesel have similar viscosities. The combustion enthalpy of biodiesel is slightly lower, but its cetane number is higher and so is its flash point.

\section{Emissions}

Most of the emissions produced by fossil fuels are higher than those generated by biodiesel. 
Table 1

Physicochemical properties of biodiesel

\begin{tabular}{|c|c|c|c|c|c|c|c|}
\hline $\begin{array}{l}\text { Methyl ester } \\
\text { of oil }\end{array}$ & $\begin{array}{l}\text { Kinematic } \\
\text { viscosity }\end{array}$ & $\begin{array}{l}\text { Cetane } \\
\text { number }\end{array}$ & $\begin{array}{c}\text { Thermal } \\
\text { power }\end{array}$ & $\begin{array}{l}\text { Meeting } \\
\text { point }\left({ }^{\circ} \mathrm{C}\right)\end{array}$ & $\begin{array}{l}\text { Flash } \\
\text { point }\end{array}$ & Density & $\begin{array}{l}\text { Sulphur } \\
\text { content }\end{array}$ \\
\hline & $\left(\cdot 10^{-6} \mathrm{~m}^{2} / \mathrm{s}\right)$ & & $(M J / L)$ & & $\left({ }^{\circ} \mathrm{C}\right)$ & $(\mathrm{kg} / \mathrm{L})$ & $(\% w)$ \\
\hline Babassu $^{1}$ & $3.6\left(37.8^{\circ} \mathrm{C}\right)$ & 63 & 31.8 & 4 & 127 & 879 & \\
\hline Corn, used ${ }^{3}$ & $6.2\left(30^{\circ} \mathrm{C}\right)$ & 63.9 & 42.3 & & 166 & 884 & 0.0013 \\
\hline Diesel $^{2}$ & $2.8\left(30^{\circ} \mathrm{C}\right)$ & 58 & 42.7 & & 59 & 833 & 0.05 \\
\hline Olive $^{1}$ & $5.7\left(37.8^{\circ} \mathrm{C}\right)$ & 62 & 33.5 & 13 & 164 & 880 & \\
\hline Olive $^{2}$ & $4.4\left(40^{\circ} \mathrm{C}\right)$ & $64.3-70$ & 32.4 & & & 875 & \\
\hline Peanut $^{1}$ & $4.9\left(37.8^{\circ} \mathrm{C}\right)$ & 54 & 33.6 & 5 & 176 & 883 & \\
\hline Rapeseed, used ${ }^{3}$ & $9.5\left(30^{\circ} \mathrm{C}\right)$ & 53 & 36.7 & & 192 & 895 & 0.002 \\
\hline Rapeseed $^{2}$ & $4.2\left(40^{\circ} \mathrm{C}\right)$ & $51-59.7$ & 32.8 & & & 882 & \\
\hline Soybean ${ }^{1}$ & $4.5\left(37.8^{\circ} \mathrm{C}\right)$ & 45 & 33.5 & 1 & 178 & 885 & \\
\hline Soybean $^{2}$ & $4.0\left(40^{\circ} \mathrm{C}\right)$ & $45.7-56$ & 32.7 & & & 880 & \\
\hline Sunflower ${ }^{1}$ & $4.6\left(37.8^{\circ} \mathrm{C}\right)$ & 49 & 33.5 & 1 & 183 & 860 & \\
\hline
\end{tabular}

Note: ${ }^{1}$ Srivastava et al., 2000; ${ }^{2}$ Varese et al., 1996; ${ }^{3}$ Yamane et al., 2001.

Biodiesel does not generate $\mathrm{SO}_{2}$ emissions, its combustion is more effective because of its higher oxygen content, and particulate matter and $\mathrm{CO}$ emissions are lower (Scragg et al., 2003), as shown in Table 2. Emissions of hydrocarbon compounds are also reduced by biodiesel, but $\mathrm{NO}_{x}$ become higher (Canakci, 2007). Biodiesel emits $4.7 \%$ more $\mathrm{CO}_{2}$ than petroleum diesel, but most of it is captured by plants during the growth stage, and therefore its contribution to the greenhouse effect is negligible.

Biodiesel also has better lubricating properties, extending engine life and reducing noise level (Lapuerta et al., 2005). Since it has good solvent properties, the motor piping is kept clean from cinder. The drawback is that natural rubber sleeves (still used in old engines) are dissolved by biodiesel, but this can be easily avoided, as these parts are made today of synthetic rubber.

\section{Work in engines}

Biodiesel shows similar thermal efficiency to diesel fuel, but has a higher fuel consumption, because of its lower energy content. Exhaust gas temperature is often lower than for diesel, which means that the combustion of biodiesel starts earlier and has a longer expansion period. The start of fuel injection occurs earlier in biodiesel than with diesel fuel, as a result of their different physicochemical properties. The ignition delay period is also shorter in the case of biodiesel (Canakci, 2007).

\section{Toxicity}

The high octane number of the oxygenated compounds present in biodiesel does not require the addition of antiknock compounds. Therefore, emissions derived from polycyclic aromatic hydrocarbons (PAHs) and their nitroderivatives (NAPH's) are reduced. PAHs are reduced by $85 \%$, except benzo-antracen which is only reduced by 50 $\%$. Also, NAPH's (2-nitrofluorene and 1-nitropyrene) are drastically reduced by $90 \%$ (Sharp, 1998).

\section{Biodegradability}

Tests carried out at the University of Idaho have shown that degradation of biodiesel in an aqueous solution was $95 \%$ in 28 days, a period which is similar to that of sugar. For the same period of time, only $40 \%$ of petroleum diesel was degraded. Petroleum diesel is composed of a mixture of alkenes, branched alkenes, cycloalkenes and aromatic hydrocarbons. A wide range of micro-

Table 2

Comparison between emission levels of biodiesel (pure or mixed) and fossil fuel in automotive engines

\begin{tabular}{lccc}
\hline $\begin{array}{l}\text { Emission } \\
(\mathbf{k g} / \mathbf{1 0 0} \mathbf{~ k m )}\end{array}$ & $\begin{array}{c}\text { Biodiesel } \\
\mathbf{1 0 0} \%\end{array}$ & $\begin{array}{c}\text { Biodiesel } \\
\mathbf{3 0} \%\end{array}$ & Diesel \\
\hline $\mathbf{C O}$ & 0.37 & 0.43 & 0.46 \\
Hydrocarbons & 0.03 & 0.04 & 0.04 \\
$\mathrm{NO}_{\mathbf{x}}$ & 2.73 & 3.37 & 3.64 \\
$\mathrm{Particulate} \mathrm{matter}_{\mathrm{CO}_{2}}$ & 0.62 & 1.48 & 1.85 \\
$\mathbf{S O}_{2}$ & 0.87 & 3.53 & 4.67 \\
& 0 & 1.14 & 1.62 \\
\hline
\end{tabular}


organisms can degrade alkenes, but aromatic compounds are more difficult to degrade (Zhang et al., 1998). Moreover, since petroleum diesel contains less oxygen than biodiesel, it is less biologically active.

It has been demonstrated that mixtures of biodiesel and petroleum diesel accelerate biodegradability. The rate of biodegradation of a B20 mixture $(20 \%$ of biodiesel and $80 \%$ of fossil fuel) is twice that of the fossil fuel (Tyson, 2001).

\section{Drawbacks}

Biodiesel has some drawbacks that have to be taken into account. Its melting point (equivalent to CFPP of a petroleum fuel) varies from 0 to $-5{ }^{\circ} \mathrm{C}$, which is slightly high and may result in a low fluidity in cold environments (Foglia et al., 1997).

The pour point (point at which the fuel stops fluidization) depends strongly on the composition of the biodiesel mixture. Saturated fatty acid methyl esters crystallize at a higher temperature than unsaturated ones. Depending on the raw material, biodiesel contains different ratios of saturated/unsaturated esters. A possible approach to solving this problem is by adding additives to the biodiesel (e.g., butyl oleate). Biodiesel can also be produced with secondary or branched alcohols. These compounds destroy the ester chain order, decreasing the melting point and the pour point (Salis et al., 2005).

At present, biodiesel production is at relatively small scale and limited logistics, it is still not economically competitive with petroleum diesel, and relies on tax benefits and subsidies. However, optimization studies along with appropriate logistics, may lead to a cost-competitive product.

\section{BIODIESEL PRODUCTION PROCESSES}

Three kinds of processes have been studied to produce biodiesel from vegetable oils and waste cooking oils, namely: pyrolisis, emulsification, and transesterification.

Pyrolisis consists of the application of thermal energy in the presence of air or oxygen, to produce a chemical modification. The thermal decomposition of triglycerides yields alkanes, alkenes, alkadienes, aromatic compounds and carboxylic acids. Because of the wide variety of reaction pathways, different reaction products are obtained. Despite the fact that products are chemically similar to petroleum diesel, oxygen removal during thermal cracking decreases some of the environmental benefits of these renewable oils (Ma and Hanna, 1999).

Microemulsions have been prepared with solvents such as methanol, ethanol and 1-butanol in order to lower the high viscosity of biodiesel. These microemulsions are isotropic, clear, and are thermodynamically stable dispersions of oil, water and a surfactant; a cosurfactant is often dispersed, using amphiphilic compounds. This process yields a fuel with lower viscosity, but injection in the engines is not so efficient, and a coarse deposition and incomplete combustion is generated (Tsai and Chang, 1993; Isono et al., 1995).

The transesterification process, so-called alcoholysis, is the displacement of an alcohol in the ester molecule by another alcohol as in a hydrolysis reaction, using alcohol instead of water. Suitable alcohols are methanol, ethanol, propanol, butanol and amyl alcohol. Methanol is the most commonly used, because of its low cost and good physicochemical properties. Transesterification of oils, thus reduces the viscosity of triglycerides, and also improves the physical properties of the final product (cetane number, injection efficiency), resulting in a better fuel. Fatty acid methyl esters obtained by transesterification can be employed directly, and with similar energy efficiency as petroleum diesel. Recently, studies on transesterification in supercritical media have also been carried out (Demirbas, 2003; Madras et al., 2004).

Transesterification involves several reversible consecutive reactions (Schwab et al., 1987). A triglyceride is transformed successively into diglyceride, monoglyceride and, finally, in glycerol. One mole of ester is released in each step.

Kinetic mechanisms vary, depending on the oil/alcohol molar ratio. For instance, a pseudo-first order reaction mechanism has been suggested for sunflower oil, with an oil/alcohol molar ratio of 30:1, while a second order kinetics mechanism has been suggested for the same oil when a 6:1 oil/alcohol molar ratio is employed (Freedman et al., 1986).

\subsection{Acid Transesterification}

Transesterification of triglycerides is catalyzed by inorganic acids, such as sulphuric, phosphoric, hydrochloric, and sulphonated organic acids. This catalytic process produces high conversions, at a slow rate, and more than a day to reach complete conversion is needed. An excess of alcohol increases the conversion, but makes glycerol recovery more complicated. Hence, optimization is required to find the best relationship between alcohol and the raw material. This process is, however, the most appropriate for triglycerides with a high content in free fatty acids and water.

Acid-catalyzed transesterification starts by mixing the oil directly with the acidified alcohol, so that separation and transesterification occur in a single step, with the alcohol acting both as solvent and as esterification reagent. Sunflower oil transesterification with acidified methanol yields fatty acid methyl esters with higher conversion to that obtained in the alkaline process (Harrington and D'Arcy-Evans, 1985a; Harrington and D'ArcyEvans, 1985b).

The proposed reaction mechanism consists of the protonation of the carbonyl oxygen group by the acid that, in the presence of an alcohol, generates the corresponding fatty acid ester (Meher et al., 
2006). Reaction kinetics are typically expected to follow a pseudo-first order model, when an alcohol excess is present to shift the equilibrium.

In-situ transesterifications, where the simultaneous extraction of neutral lipids and bran is produced, have also been proposed for soybean oil (Kildrian et al., 1996) and rice bran oil (Özgül and Türkay, 1993; Lai et al., 2005).

\subsection{Alkali-catalyzed transesterification}

Alternative catalysts for triglycerides transesterification to biodiesel are alkaline hydroxides, such as sodium and potassium hydroxide. Reactions of methanol or ethanol with a number of vegetable oils, crude or refined or even waste cooking oils have been performed using hydroxides as catalyst. At present, the industrial biodiesel synthesis is being carried out using these alkaline catalysts, since reaction rates are much higher (even 4000 times) than for acid catalysis. Better efficiencies are obtained if the alcoxyde is formed before transesterification.

The reaction mechanism has three main steps. The first step involves an attack on the ester by the alcoxyde ion, to form a tetrahedrical intermediate. The reaction between this intermediate with an alcohol molecule generates an alcoxyde in the second step. In the last step, ester and diglycerides are produced. The reaction proceeds in a similar way with the diglyceride and the monoglyceride, liberating three ester molecules and glycerol (Meher et al., 2006; Vicente et al., 2001).

A flow diagram of biodiesel production is shown in Figure 1. In the first step methanol and oil are mixed (1), then the mixture is pumped into the esterification reactor (2). Once the reaction is complete, more methanol and catalyst are added and the mixture leaves the transesterification reactor (3). Then the mixture is pumped into a mixing tank (4) where it is neutralized with mineral acid. The stream is then sent to a flash separator (5) to remove the excess methanol that is condensed (6) and recycled to the storage vessel (7). The bottom stream which contains glycerol, biodiesel and impurities is centrifuged (8), and the light phase, mainly biodiesel, is dried (9) and stored (10). The heavy phase, which contains $90 \%$ glycerol, is partially purified and stored (11).

The transesterification reaction involves some critical parameters which strongly influence the final yield (Marchetti et al., 2007):

Water activity: In alkali-catalyzed transesterifications, both fatty acids and alcohols have to be anhydrous, because water displaces the equilibrium reaction towards saponification, generating soap and reducing the final yield, consuming catalyst and increasing the viscosity and gel formation, which results in a more difficult glycerol separation (Freedman et al., 1984).

Free fatty acid content: Several studies have revealed that in order to achieve high conversions,

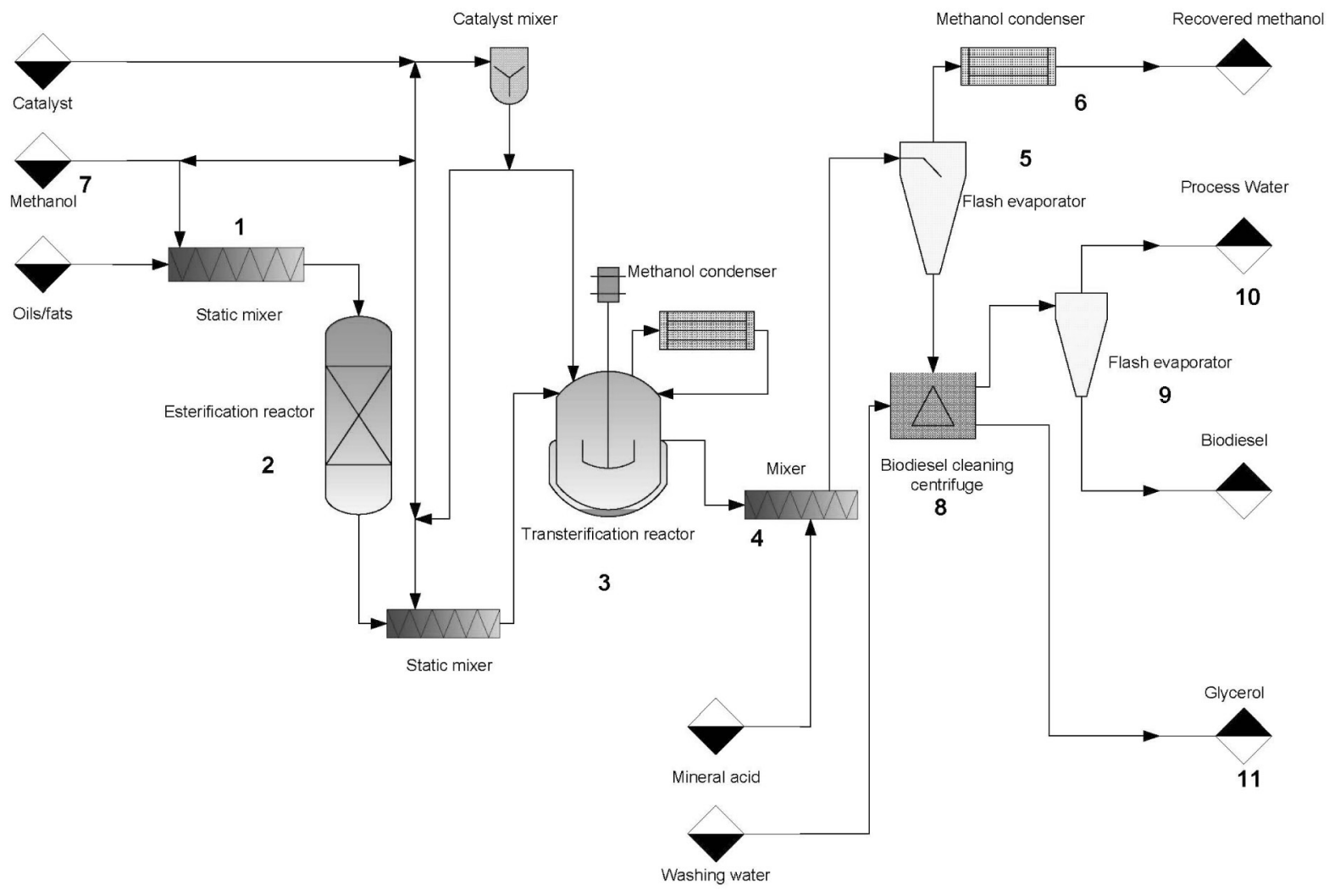

Figure 1.

Flowsheet of biodiesel synthesis industrial process (Adapted from Larosa et al, 2005). 
the maximum free fatty acid content must be at most 0.5\% (Ma et al., 1998; Bradshaw and Meuly, 1944; Feuge and Grose; 1949). This parameter is, nevertheless, less critical than the water content. Free fatty acid reduces the yield since the free fatty acids consume the alkali catalyst, because they take part in the neutralization reaction (Turck, 2002; Meher et al., 2006). Ethyl ester synthesis presents additional difficulties due to the formation of emulsions during the ethanolysis. Both methanol and ethanol are partially immiscible with the oil (ethanol being more soluble than methanol), therefore vigorous stirring is needed to enhance mass transfer. In the case of methanolysis, the emulsion breaks easily to form a heavy glycerol layer, and a light ester layer. In ethanolysis, this emulsion is more stable.

Oil/alcohol molar ratio: The reaction stoichiometry involves three moles of alcohol for each mole of triglyceride reacted to obtain three moles of ester and one mol of glycerol. Being an equilibrium reaction, an alcohol excess displaces the reaction to ester formation and higher conversions are reached. Nevertheless, a large excess of alcohol makes glycerol separation difficult due to the increasing solubility of glycerol in the alcohol. Moreover, when the glycerol is kept in the solution, it displaces the equilibrium to the left hand side, decreasing the ester yield. Nevertheless, yield and optimum rate depend on the oil used. For example, soybean, sunflower, peanut and cotton seed oils have an optimum ratio of $6: 1$ (Krisnangkura and Simamaharnnop, 1992). This ratio is used at industrial scale in order to obtain high yields, almost $98 \%$ (see Figure 2).

Ethyl ester synthesis presents additional difficulties because of the formation of emulsions

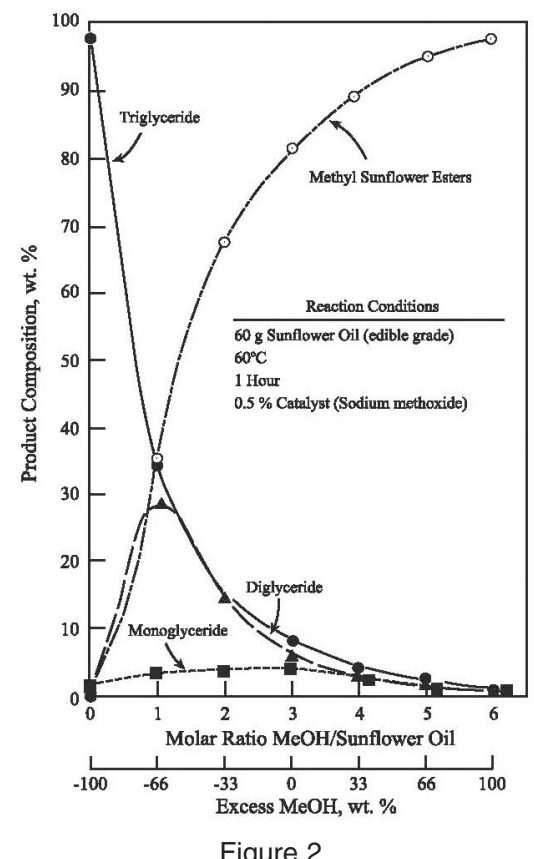

Figure 2

Effect of the alcohol to oil molar ratio in product profile during the transesterification of sunflower oil (Reproduced with permission from Van Gerpen, 2006). during the ethanolysis reaction. Both methanol and ethanol are partially immiscible in the oil (methanol being more insoluble than ethanol). Therefore, vigorous stirring is employed to enhance mass transfer. In the case of methanolysis, the emulsion breaks easily to form a heavy glycerol layer, and a light ester layer. In ethanolysis, this emulsion is more stable.

Finally, the type of catalyst is a key factor. Generally, alkaline catalysts lead to much faster rates than acid catalysts, and hence they are the most often used, except if free fatty acid content is high. Sodium methoxyde is more effective than sodium hydroxide, since the reaction between $\mathrm{NaOH}$ and the alcohol generates a small amount of water which decreases catalytic efficiency (Hartman, 1956). These catalysts have the drawback of being more expensive and also more difficult to handle (Vicente et al, 2004). Product profile also depends greatly on the raw material and the catalyst. For example, tallow and waste cooking oils produce fuel with better ignition properties if amines (diethylamine) are used instead of sodium methoxyde. However, because of the low cost of sodium methoxyde, it is most commonly employed.

The use of alkaline metallic compounds in rapeseed oil transesterification has also been studied. The reaction is carried out with methoxide ions present in the reaction media. Hydroxides, oxides and metallic alcoxydes that catalyze the reaction actually slow it down, because the mixture is an oil-alcohol-catalyst three-phase system, and reaction kinetics is mass transfer limited (Meher et al., 2006).

However, transesterification with ethanol is more effective when sodium hydroxide is used as catalyst, because it raises the solubility of the alcohol in the oil medium (Peterson et al., 1996).

Other heterogeneous metallic complex catalysts, such as those with $\mathrm{Zn}$, have also been used at laboratory scale (Kim et al., 2004; Bournay et al., 2005).

\section{NEW TRENDS}

Some new advances are now being studied in order to improve the efficiency of the biodiesel synthesis process.

Glycerol recovery and revalorization is important for the economy of the production of biodiesel from vegetable oils; glycerol is the main transesterification reaction by-product and it has to be highly purified to have a reasonable market.

New kinds of raw material, like Brassica carinata and oil from microalgae, are being considered to transesterificate their oil.

The use of ethanol, which can be also obtained from biomass, in the transesterification reaction, will provide the synthesis of a $100 \%$ green fuel (Martínez and Aracil, 2006). 
Enzymatic transesterification has shown to be a good alternative at laboratory scale, and it might be scaled-up for bioethanol plants. Enzymatic reactions using lipases have been reported to give good yields of methyl esters with different raw materials (Mukherjee, 1988, Breivik et al., 1997, Shimada et al., 1997, Shimada et al., 1998, Uosukainen et al., 1999, Wu et al., 1999, Vacek et al., 2000, Soumanou and Bornscheuer, 2003, Shah et al., 2004, Zhang et al., 2003).

Lipases, both intra and extracellular, can effectively catalyze triglyceride transesterification to obtain fatty acid esters, both aqueous and nonaqueous media, and can eliminate inorganic catalyst processes. Glycerol can easily be recovered with simple separation processes. Nevertheless, using enzymes becomes more expensive.

Lipase catalysed synthesis can be carried out in biphasic mixtures using an emulsifier, or in organic media employing a solvent, but the easiest way is using a medium without solvents, directly with the reagents mixture. This decreases the solvent cost and increase reagent concentration and productivity.

For the use of enzymes, there are some critical factors: There is a minimum water content needed by the lipase, below which it does not work; alcohol has an effect on the reaction, being methanol the most commonly employed; the effect of temperature effect is significant because instead of increasing the reaction rate by increasing temperature, enzymes can become denatured at high temperatures; and of course the raw material is important, because not all oils have the same amount or type of fatty acids, and lipase specificity can become more attractive in some oils than in others.

\section{CONCLUSIONS}

The catalytic modification of vegetable oils is a promising method to obtain a substitute fuel for diesel engines

Among various types of modification, the transesterification process is more economical, easier and faster, producing a stable product which can be used directly in current engines. Transesterification yield is often better when employing a basic catalyst, like sodium methoxyde, although acid catalysis might give better results, provided that free fatty acid content is high.

Both methanol and ethanol can be used as esterifying agents, being methanol the most often used nowadays. Nevertheless, the use of ethanol would produce a fully renewable and more environmentally friendly fuel.

In the transesterification process, reaction variables such as water and free fatty acid content should be carefully controlled to reach high yields, and so should the type of catalyst. Reaction parameters are strongly influenced by the type of oil employed, and a case to case optimization is required.

\section{REFERENCES}

Aracil J, Vicente M, Martínez M, Poulina M. 2006. Biocatalytic processes for the production of fatty acid esters. J. Biotechnol. 124. 213-223.

Bournay L, Casanave D, Delfort B, Hillion G, Chodorge JA. 2005. New heterogeneous process for biodiesel production: A way to improve the quality and the value of the crude glycerine produced by biodiesel plants. Catal. Today 106. 190-192.

Bradshaw GB, Meuly WC. Preparation of detergents. U.S. Patent 2.360.844 (1944).

Breivik H, Haraldsson GG, Kristinsson B. 1997. Preparation of highly purified concentrates of eicosapentanoic acid and docosahexanoic acid, J. Am. Oil Chem. Soc. 74, 1425-1429.

Canakci M. 2007. Combustion characteristics of a turbocharged DI compression ignition engine fuelled with petroleum diesel fuels and biodiesel. Bioresource Technol. 98. 1167-1175.

Demirbas A. 2003. Biodiesel fuel from vegetable oils via catalytic and non catalytic supercritical alcohol transesterifications and other methods: a survey. Energ. Convers. Manag. 44. 2093-2109.

Dossat V, Combes D, Marty A. 1999. Continuous enzymatic transesterification of high oleic sunflower oil in a packed bed reactor: influence of the glycerol production. Enzyme Microb. Tech. 25. 194-200.

Dossat V, Combes D, Marty A. 2002. Lipase-catalysed transesterification of high oleic sunflower oil. Enzyme Microb. Tech. 30. 90-94.

Feuge RO, Grose T. 1949. Modification of vegetable oils. VII. Alkali catalyzed interesterification of peanut oil with ethanol. J. Am. Oil Chem. Soc. 26. 97-102.

Freedman B, Pryde EH, Mounts TL. 1984. Variables affecting the yields of fatty esters from transesterified vegetables oils. J. Am. Oil Chem. Soc. 61. 1638-1643.

Freedman B, Butterfield RO, Pryde EH. 1986. Transesterification kinetics of soybean oil. J. Am. Oil Chem. Soc. 63. 1375-1380.

Fukuda, H, Kondo A, Noda H. 2001. Biodiesel fuel production by transesterification. J. Biosci. Bioeng. 92 (5). 405-416

Harrington KJ, D'arcy-Evans C. 1985a. A comparison of conventional and in situ methods of transesterification of seed oil from a series of sunflower cultivars. J. Am. Oil Chem. Soc. 62. 1009-1013.

Harrington KJ, D'arcy-Evans C. 1985b. Transesterification in situ of sunflower seed oil. Ind. Eng. Chem. Prod. Res. Dev. 24. 314-318.

Hartman L. 1956. Methanolysis of triglycerides. J. Am. Oil Chem. Soc. 33. 129-132.

Isono Y, Nabetani H, Nakajima M. 1995. Interesterification of triglyceride and fatty acid in a microaqueous reaction system using lipase-surfactant complex. Biosci. Biotech. Bioch. 59. 1632-1635

Kildrian G, Özgül S, Türkay S. 1996. In situ alcoholysis of soybean oil. J. Am. Oil Chem. Soc. 73. 225-228.

Kim H-J, Kang B-S, Kim M-J, Park YM, Kim D-K, Lee J-S, Lee K-Y. 2004. Transesterification of vegetable oil to biodiesel using heterogeneous base catalyst. Catal. Today 93-95. 315-320.

Krisnangkura K, Simamaharnnop R. 1992. Continuous transmethylation of palm oil in a organic solvent. J. Am. Oil Chem. Soc. 69. 166-169.

Lai CC, Zullaikah S, Ramjan Vadi S, Ju YH. 2005. Lipasecatalyzed production of biodiesel from rice bran oil. J. Chem. Technol. Biot. 80. 331-337. 
Lapuerta M, Armas O, Ballesteros R, Fernández J. 2005. Diesel emissions from biofuels derived from Spanish potential vegetable oils. Fuel 84. 773-780.

Larosa RJ. 2005. Situación actual del biodiesel. Ing. Quim. 421. 97-194.

Ma F, Clements LD, Hanna MA. 1998. Biodiesel fuel from animal fat. Ancillary studies on transesterification of beef tallow. Ind. Eng. Chem. Res. 37. 3768-3771.

Ma F, Hanna M A. 1999. Biodiesel production: a review. Bioresource Technol. 70. 1-15.

Madras G, Kolluru C, Kumar R. 2004. Synthesis of biodiesel in supercritical fluids, Fuel 83. 2029-2033.

Marchetti JM, Miguel VU, Errazu AF. 2007. Possible methods for biodiesel production, Renew. Sust. Energ. Rev. 11. 1300-1311.

Martínez M, Aracil J. 2006. Biodiesel: Current trends and technical developments in Spain. Proceedings of the $6^{\text {th }}$ ANQUE International Congress of Chemistry "Chemistry and Sustainable Developments". Abstracts Book, Vol. 2. T3-33.

McCoy M. 1998. Biomass ethanol inches forward. Chem. Eng. News 76. 29-32.

Meher LC, Vidya-Sagar D, Naik SN. 2006. Technical aspects of biodiesel production by transesterificationa review. Renew. Sust. Energ. Rev. 10. 248-268.

Mittelbach M. 1990. Lipase-catalyzed alcoholysis of sunflower oil, J. Am. Oil Chem. Soc. 67. 168-170.

Mukherjee K, Kiewitt I. 1988. Preparation of esters resembling natural waxes by lipase-catalyzed reactions, J. Agr. Food Chem., 36, 1333-1336.

Online Medical Dictionary, published by Medical Oncology Department. Newcastle University. October (2002).

Özgül S, Türkay S. 1993. In situ esterification of rice bran oil with methanol and ethanol. J. Am. Oil Chem. Soc. 70. 145-147.

Peterson C, Möller G, Haws R, Zhang X, Thompson J, Reece D. 1996. Ethyl ester process scale-up and biodegradability of biodiesel. USDA. 93-COOP-18627.

Salis A, Pinna M, Monduzzi M, Solinas V. 2005. Biodiesel production from triolein and short chain alcohols through biocatalysts. J. Biotechnol. 119. 291-299.

Sarbolouki MN, Moacanin J. 1980. Chemicals from biomass. The U.S. prospects for the turn of the century. Sol. Energy 25. 303-315.

Schwab AW, Bagby MO, Freedman B. 1987. Preparation and properties of diesel fuels from vegetables oils. Fuel 66. 1372-1378.

Scragg AH, Morrison J, Shales SW. 2003. The use of a fuel containing Chlorella vulgaris in a diesel engine. Enzyme Microb. Tech. 33. 884-889.

Shah S, Sharma S, Gupta MN. 2004. Biodiesel preparation by lipase-catalyzed transesterification of Jatropha oil. Energ. Fuel. 18. 154-159.

Sharp CA. Characterization of biodiesel exhaust emissions for EPA 211 (b). San Antonio Southwest Research Institute. Report no 08-1039A. January (1998).

Shaw J-F, Wang D-L, Wang Y-J. 1991. Lipase-catalysed ethanolysis and isopropanolysis of triglycerides with long-chain fatty acids. Enzyme Microb. Tech. 13. 544546.

Shimada Y, Sugihara A, Nakano H, Kuramoto T, Nagao T, Gemba M, Tominaga Y. 1997. Purification of docosahexanoic acid by selective esterification of fatty acids from tuna oil with Rhizopus delemar lipase. J Am. Oil Chem. Soc. 74. 97-101.

Shimada Y, Maruyama K, Sugihara A, Baba T, Komemushi S, Moriyama S, Tominaga Y. 1998. Purification of ethyl docosahexanoate by selective alcoholysis of fatty acids ethyl esters with immobilized Rhizomucor miehei lipase. J Am. Oil Chem. Soc. 75. 1565-1571.

Soumanou M, Bornscheuer UT. 2003. Improvement in lipase-catalyzed synthesis of fatty acid methyl esters from sunflower oil. Enzyme Microb. Tech. 33, 97-103.

Srivastava A, Prasad R. 2000. Triglycerides-based diesel fuels. Renew. Sust. Energ. Rev. 4. 111-133.

Turck R. Method for producing fatty acid esters of monovalent alkyl alcohols and use thereof. U.S. Patent 0.156.305 (2002).

Tsai SW, Chang CS. 1993. Kinetics of lipase-catalyzed hydrolysis of lipids in biphasic organic-aqueous systems. J. Chem. Technol. Biot. 57. 147-154.

Tyson K. 2001. Biodiesel handling and use guidelines. National Resource Energy Laboratory. USDOE, Golden, $\mathrm{CO}$

Uosukainen E, Lämsä M, Linko YY, Linko P, Leisola M. 1999. Optimization of enzymatic transesterification of rapeseed oil ester using response surface and principal component methodology. Enzyme Microb. Tech. 25. 236-243.

Vacek M, Zarevucka M, Wimmer Z, Stransky K, Koutek B, Mackova M, Demnerova K. 2000. Lipase-mediated hydrolysis of blackcurrant oil. Enzyme Microb. Tech. 27. 531-536.

Van Gerpen J. 2006. Biodiesel Processing and Production. Fuel Process Technol., 86 (19). 1097-1107.

Varese R, Varese M. 1996. Methyl ester biodiesel: opportunity or necessity? Inform. 7, 816-824.

Vicente Crespo G, Martínez Rodríguez M, Aracil Mira J. 2001. Biodiesel, una alternativa real al gasóleo mineral. Ing. Quim. 377. 135-145.

Vicente G, Martínez M, Aracil J. 2004. Integrated biodiesel production: a comparison of different homogeneous catalysts systems. Bioresource Technol. 92. 297-305.

Wright JD. 1988. Ethanol from biomass by enzymatic hydrolysis. Chem. Eng. Process 84. 62-73.

Wu WH, Foglia TA, Marmer WN, Phillips JG. 1999. Optimizing production of ethyl esters of grease using $95 \%$ ethanol by response surface methodology. $J$. Am. Oil Chem. Soc. 76. 517-521.

Yamane K, Ueta A, Shimamoto Y. 2001. Influence of physical and chemical properties of biodiesel fuel on injection, combustion and exhaust emission characteristics in a DC-Cl engine. Proc 5th Int. Symp. On Diagnostics and Modelling of Combustion in Internal Combustion Engines (COMODIA 2001). Nagoya. 402-409.

Zhang X, Peterson C, Reece D, Haws R, Möller G. 1998. Biodegradability of biodiesel in aquatic environment. Trans. Am. Soc. Eng. 41. 1423-1430.

Zhang Y, Dubé MA, Mclean DD, Kates M. 2003. Biodiesel production from waste cooking oil: 1.- Economic assessment and sensitivity analysis, Bioresource Technol. 90. 229-240.

Recibido: 31/05/07 Aceptado: 01/10/07 